\title{
Mentesítő rendszerek fejlesztése Magyarországon a NATO-csatlakozást követően m.resz
}

\begin{abstract}
A tanulmány első két részében a szerző bemutatta a rendszerváltást követően Magyarország fegyveres testületeinél és hivatásos katasztrófavédelmi szervezeteinél alkalmazásba vett különböző mentesítő megoldásokat. Az érdeklődők megismerhették a különböző rendszerek képességeit, főbb összetevőit és kapacitásait, emellett az alkalmazási területeik rendszerezésére és öszszehasonlítására is sor került. A tanulmány harmadik része rávilágít a főbb képességhiányokra, és ismerteti a nemzetközi együttmúködések során kidolgozott új koncepciókat, fejlesztési irányokat, lehetőségeket.
\end{abstract}

\section{A HAZAI MENTESITŐRENDSZER-KÉPESSÉGEK TOVÁBBFEJLESZTÉSI LEHETŐSÉGEI}

A NATO-csatlakozást követően elindult fejlesztések nem álltak meg, folyamatosan új kihívások jelennek meg mind a katonai, mind a polgári területeken, amelyekre a mentesítö szakterületeknek is megfelelő válaszokat kell adniuk. A nemzetközi együttműködések és a hazai fejlesztések során a szakemberek megvizsgáltak néhány új eljárási koncepciót, fejlesztési irányt és lehetőséget, és a képességhiányok meghatározását követően megállapították, hogy közülük több alapját képezheti a hazai mentesítési képességek további bővítésének.

Ahhoz azonban, hogy meghatározzuk az esetleges képességhiányokat, ismerni kell a magyar fegyveres testületek és hivatásos katasztrófavédelmi szervezetek által már alkalmazásba vett, különböző mentesítő megoldásokat és azok főbb képességeit. Csak ezek áttekintése után lehet eldönteni, hogy szükség van-e fejlesztésre, és ha igen, akkor a meglévő készleteket kell-e bővíteni/módosítani, vagy új egységek „rendszerbe állítása” szükséges.

\section{4. ábra. Szennyezőanyag-felfogó fólia (SZAFF) helikopter} mentesítéshez telepítve

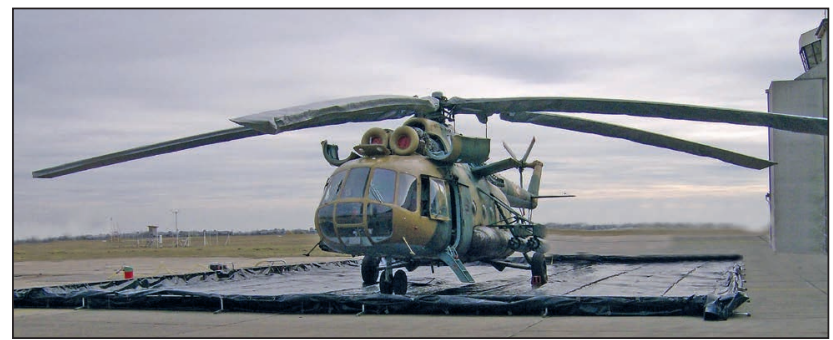

NKE Katonai Műszaki Doktori Iskola. ORCID: 0000-0003-3571-652X
A világméretű terrorizmus megjelenésével a tömegpusztító fegyverek alkalmazása, mint katonai probléma, illetve a vegyi balesetek, ipari katasztrófák, mint a polgári terület problémái közötti határ elmosódott. Ahogy a lakosság fenyegetettsége miatt a polgári védelem és egyéb civil szervezetek szakembereinek meg kell ismerniük a mérgező harcanyagokat és biológiai ágenseket, továbbá szerepet kell vállalniuk az ellenük való védelemben, ugyanúgy a honvédség ABV-védelmi erőinek is részt kell vállalniuk ipari veszélyes anyagok okozta káresemények felszámolásában (lásd vörösiszap katasztrófa ${ }^{27}$, COVID-19 pandémia ${ }^{28}$ elleni védekezés).

\section{KÉPESSÉGHIÁNYOK A MENTESITEÉS TERÜLETÉN}

A képességhiányokat vizsgálhatjuk abból a szempontból, hogy a fegyveres testületek és hivatásos katasztrófavédelmi szervezetek által alkalmazott rendszereknél milyen szakmai kihívásra hiányoznak megoldások, vagy hol szükséges növelni a már meglévő képességeket. Együtt vizsgálva ezt a kérdést akár az ipari szereplőknél, akár a közszolgáltatást ${ }^{29}$ nyújtó vagy közfeladatot ellátó társaságoknál található képességekkel, a képességhiányokat nemzeti szinten azonosithatjuk.

Amennyiben a mentesítés tárgya alapján kialakított kategóriák szerinti hiányokat vizsgáljuk, úgy általánosságban elmondható, hogy az alkalmazók kialakították az önmentesítési képességeiket, vagy legalább azok mintarendszereit. Az önmentesítő képességek kifejezés nem az egyéni mentesítő csomagokat ${ }^{30}$ jelenti. Az ABV-szennyezett területen szakfeladatot végrehajtott első beavatkozó csoport(ok) önmentesítési és személyi mentesítési képességéhez alkalmas eszközök közé azokat a berendezéseket és felszereléseket soroljuk, amelyekkel a részleges vagy teljes mentesítés múveletei hathatók végre, támogató jelleggel, a szennyeződés bekövetkezése után. A rendszer főbb funkcionális összetevői lehetnek a védőfelszerelés mentesítő szett, a védőfelszerelés levételi hely, a személyi mentesítő szett és a vízellátó modul.

Ahol egyértelmúen meghatározható volt, hogy az adott szakmai feladat melyik szervezethez tartozik, az önmentesítéshez szükséges eszközrendszerek beszerzését követően a közvetlen feladataikhoz kapcsolódó, nélkülözhetetlen mintarendszereket is beszerezték. Ezekkel, a kisebb feladatok végrehajtása mellett képzéseket lehetett tartani, tapasztalatokat lehetett szerezni a rendszerek használatá- 
3. táblázat. A Magyar Honvédség és a BM OKF mentesítő rendszereinek főbb összetevői és kapacitásai

\begin{tabular}{|c|c|c|c|c|c|c|c|c|}
\hline & \multicolumn{4}{|c|}{ Mentesítő konténer } & \multicolumn{3}{|c|}{ Mentesítő utánfutó } \\
\hline & & Deco3000 & KMB-3000 & KMB MF & SZMK & ZMB & SMR-U & SZMF-U \\
\hline \multirow{4}{*}{ 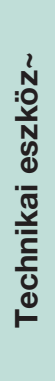 } & $\begin{array}{l}\text { előkezelő } \\
\text { modul }\end{array}$ & HD-4000 & HD-4000 & HD-4000 & & HD-4000 & & \\
\hline & $\begin{array}{l}\text { fökezelő } \\
\text { modul }\end{array}$ & 2*Sanijet_EL & 2*AMGDS & 2*Sanijet_EL & & AMGDS & & \\
\hline & $\begin{array}{l}\text { utókezelő } \\
\text { modul }\end{array}$ & 2*HDS & 2*HDS & 2*HDS & & HDS & & \\
\hline & $\begin{array}{l}\text { kapacitás } \\
\text { (db/h) }\end{array}$ & $12-16$ & $12-16$ & $12-16$ & & $4-6$ & & \\
\hline \multirow{2}{*}{$\begin{array}{l}\frac{2}{2} \\
\text { है } \\
\text { N } \\
\text { N }\end{array}$} & modul & RBA-35/KB & HWM-35C & RBA-35/KB & $\begin{array}{c}2^{*} \\
\text { HWM-35C }\end{array}$ & HWM-3000 & RBA-70/UB & RBA-70/UB \\
\hline & $\begin{array}{l}\text { kapacitás } \\
\text { (fö/h) }\end{array}$ & 120 & 60 & 60 & $240-300$ & $30-60$ & $240-300$ & $240-300$ \\
\hline \multirow{2}{*}{ 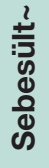 } & modul & & & & & & RBA-70/UB & RBA-70/UB \\
\hline & $\begin{array}{l}\text { kapacitás } \\
\text { (fö/h) }\end{array}$ & & & & & & $\begin{array}{c}6-10 \\
80-120\end{array}$ & $\begin{array}{c}6-10 \\
80-120\end{array}$ \\
\hline \multirow{2}{*}{ 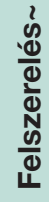 } & modul & HGU & HGU & TOP/E & & & & \\
\hline & $\begin{array}{l}\text { kapacitás } \\
\text { (fö/h) }\end{array}$ & 120 & 120 & 60 & & & & \\
\hline \multirow{6}{*}{ 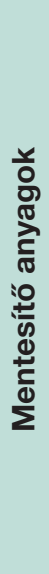 } & sugár & $\begin{array}{c}\mathrm{RM}-54 \text { / } \\
\mathrm{BX} 24\end{array}$ & RM-54 & BX24 & & & & \\
\hline & vegyi & BX24 & GDS-2000 & BX24 & & & & \\
\hline & biológiai & BX24 & $\begin{array}{l}\text { kiváltás } \\
\text { szüks. }\end{array}$ & BX24 & & & & \\
\hline & személyi & $\mathrm{RM}-21$ & $\mathrm{RM}-21$ & BX29 & $\mathrm{RM}-21$ & RM-21 & $\begin{array}{c}\text { RM-21 / } \\
\text { BX29 }\end{array}$ & RM-21 \\
\hline & belső tér & & Wofasteril & $\begin{array}{c}\text { BX60 } \\
\text { B-FOG }\end{array}$ & & & & \\
\hline & $\begin{array}{l}\text { érzékeny } \\
\text { eszköz }\end{array}$ & & & SX34 & & & & \\
\hline
\end{tabular}

* A táblázat a szerző saját szerkesztése.

ról, alkalmazhatóságáról. A szükséges mennyiségű eszköz beszerzését azonban, szinte mindenhol elsősorban a forráshiány akadályozza.

Gyakori eset, hogy több szakterület együttmüködésére van szükség a műszaki követelmények és eljárásrend kidolgozásához, valamint a beszerzéseket követően a csapatpróbához (ilyen eset például a sebesültmentesítés, amely az egészségügy és az ABV-védelem határterületét képezi). Itt egy beszerzett, megvalósított alapfelszerelés mellé még számos kiegészítő cikkre lehet szükség, új közös eljárásrendeket is ki kell dolgozni. Sok esetben azt is nehéz eldönteni, hogy ki legyen a felelős, elsősorban kinek a szakmai szempontjai és feladatvégrehajtási igényei érvényesüljenek.

Átalánosságban elmondható, hogy ma már a legtöbb feladatra létezik megoldás (személy-, sebesült-, technikai, terület-, érzékenyeszköz-mentesítés).
25. ábra. A multifunkciós konténeres mentesítő berendezés (KMB-MF) generátortér felöli nézete

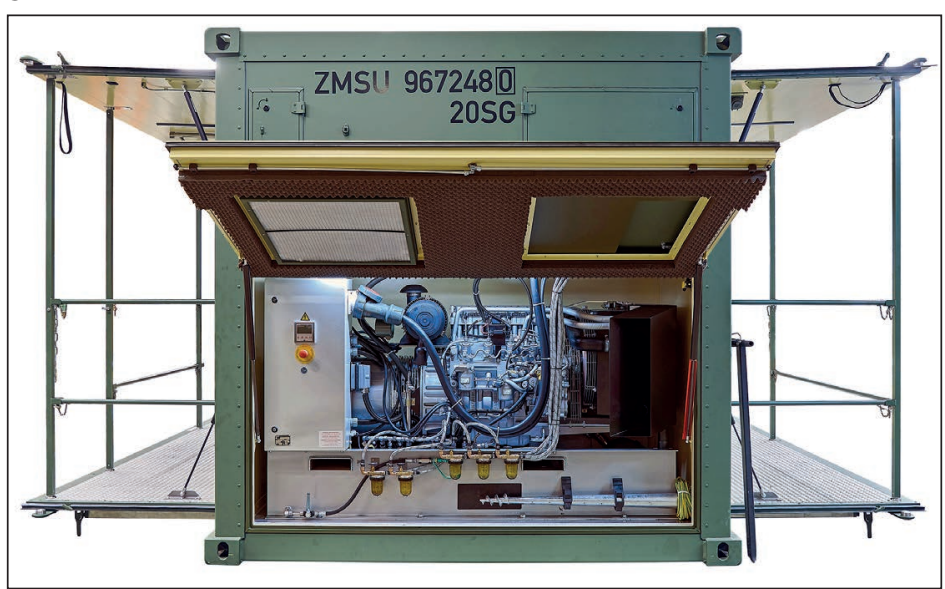


4. táblázat. Képességek és összetevők megléte a hivatásos testületek készleteiben*

\begin{tabular}{|c|c|c|c|c|c|c|c|c|c|c|c|c|c|c|}
\hline \multirow[b]{2}{*}{ 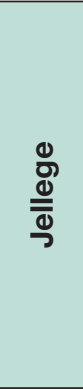 } & \multirow[b]{2}{*}{ 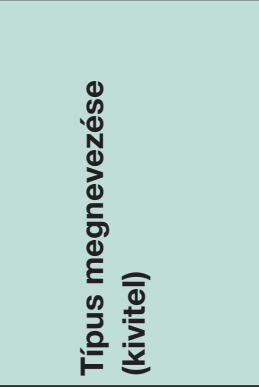 } & \multicolumn{7}{|c|}{ Mentesítési feladat } & \multicolumn{5}{|c|}{ Kiegészítők } & \multirow[b]{2}{*}{ 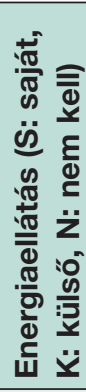 } \\
\hline & & 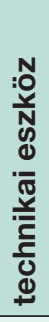 & $\stackrel{\circ}{\frac{0}{ \pm}}$ & 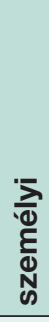 & 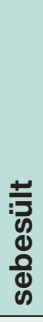 & 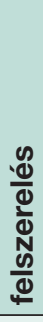 & 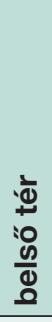 & 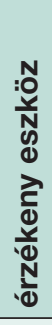 & 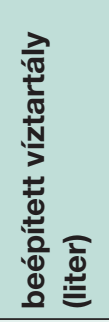 & 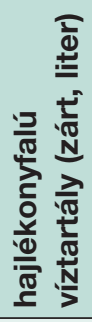 & 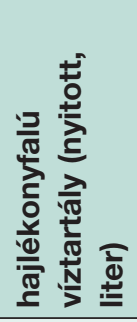 & 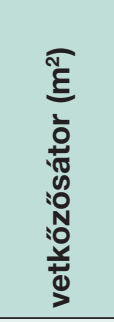 & 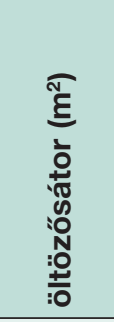 & \\
\hline \multirow{5}{*}{ 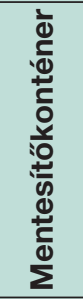 } & Decocontain3000 & V & V & V & & V & & & 3000 & 3000 & & 20 & 20 & $\mathrm{~S}$ \\
\hline & KMB-3000 & V & V & V & & V & V & & 2650 & 3000 & & 20 & 20 & S \\
\hline & KMB MF & V & V & V & & V & V & V & 2650 & 3000 & 6000 & 20 & 20 & S \\
\hline & SZMK & & & V & & & & & 1000 & & 6000 & $2 \times 37,5$ & $2 \times 55,5$ & S \\
\hline & MASZK $^{24}$ & V & V & V & & V & & V & & & & & & S \\
\hline \multirow{3}{*}{ 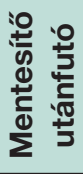 } & ZMB & V & & V & & & & & $2650^{25}$ & 3000 & & $6 / 12^{26}$ & $6 / 12^{4}$ & S \\
\hline & SMR-U & & & V & V & & & & & 3000 & 6000 & $13 / 26^{4}$ & $13 / 26^{4}$ & $\mathrm{~K}$ \\
\hline & SZMF-U & & & V & V & & & & & 3000 & 6000 & $13 / 26^{4}$ & $13 / 26^{4}$ & $\mathrm{~K}$ \\
\hline \multirow{6}{*}{ 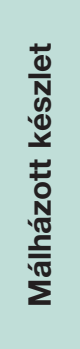 } & BMK-35 & & & V & & & & & & & & & & $\mathrm{K}$ \\
\hline & KMK-35 & & & V & & & & & & & & & & $\mathrm{K}$ \\
\hline & KML & & & V & & & & & & & & & & $\mathrm{K}$ \\
\hline & KML ADR & & & V & & & & & & & & & & $\mathrm{K}$ \\
\hline & MACAW & & & V & & V & & & & & & & & $\mathrm{N}$ \\
\hline & EMK (DS-10) & & & V & & & & & & & & & & $\mathrm{N}$ \\
\hline 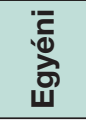 & EMCS & & & V & & & & & & & & & & $\mathrm{N}$ \\
\hline
\end{tabular}

* V = létező képesség; (a táblázat a szerző saját szerkesztése).

Amennyiben egy hiányzó képesség pótlása több alkalmazónál is szükséges, akkor esetenként elfogadható, hogy a pótlás először csak az egyiknél (ahol a legégetőbb szükség van rá, vagy szakmailag leginkább indokolt) teremtődjön meg, mert ezen a módon legalább a megfelelő tapasztalatszerzésre lehetőség nyílik.

Belátható azonban, hogy bár rövid távon, nemzeti szinten, egy katasztrófahelyzet esetén elfogadható, hogy valamely alkalmazó képességhiányát egy másik szereplő által biztosított képességgel pótolják, hosszú távon azonban csak az a megoldás felel meg az elvárásoknak, ha minden szakterület rendelkezik azokkal a képességekkel, amellyel a hozzá rendelt feladatokat maradéktalanul képes ellátni. A más alkalmazóknál szerzett tapasztalatok alapján az azonos, vagy - speciális igények esetén - kissé eltérő eszközök beszerzése és rendszeresítése szükséges.

A másik fontos megközelítés, ha az alkalmazói szinteken vizsgáljuk a képességeket és a hiányokat.

\section{MENTESITŐKÉPESSÉG-HIÁNYOK RENDSZEREZÉSE AZ ALKALMAZÓ CSOPORTOK SZERINT}

MAgYAR HonvÉdsÉG

Országos szinten a Magyar Honvédség rendelkezik a legjelentősebb mentesítő képességgel. A csapatoknál meglévő képességeken túl, az MH 93. Petőfi Sándor Vegyivédelmi Zászlóalj kiemelkedő szakmai részletezettséggel látja el a mentesítési feladatokat. Ennél a szervezetnél bizonyos területeken megfelelő az ellátottság, és a többi területen is

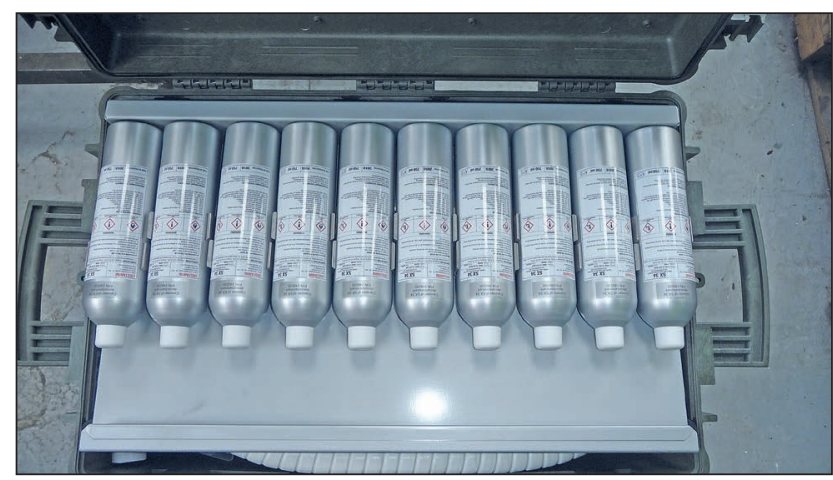

26. ábra. SX34 érzékenyeszköz-mentesítő készlet

mintarendszerként (alkalmazásra, képzésre, tapasztalatszerzésre) a megfelelő technikai eszközök rendelkezésre állnak. Az utóbbi időszakban a Magyar Honvédség már a mentesítési képességek olyan finomabb részleteire is képes összpontosítani, amilyen például az érzékeny eszközök mentesítése. Ebbe a körbe tartoznak többek között az optikai és a kommunikációs eszközök, amelyeket a szokásos mentesítő anyagok - a techikai eszközök mentesítésére általánosan alkalmazott vegyszerek - roncsolnának. Az $\mathrm{MH}$ azt az eljárást választotta, amelynél spray formában kell felhordani az érzékeny felületre a mentesítő anyagot, majd annak megszáradását követően a maradványok eltávolítását törléssel, söpréssel vagy porszívózással oldják meg. Ez az eljárás viszonylag egyszerűen és könnyen végrehajtható, ám elég sok élőmunkát igényel. Léteznek ter- 
mészetesen olyan eljárások is, amelyek sokkal jobban "gépesítettek", például a vákuumkamrás rendszer, amely tízlábas konténerbe vagy utánfutóba építhető be, ám annak magas árszintje legfeljebb a mintarendszerként való megjelenést tenné lehetővé.

\section{KATASZTRÓFAVÉDELEM}

A katasztrófavédelem tűzoltó és iparbiztonsági KML (katasztrófavédelmi mobil labor), KML-ADR (Accord européen relatif au transport international des marchandises dangereuses par route - A veszélyes áruk nemzetközi közúti szállításáról szóló európai megállapodás), a hivatásos nehéz kutató-mentő mentőszervezet, azaz a HUNOR (Hungarian National Organisation For Rescue Services), valamint a Huszár (közepes kutató-mentő csapat, amelyet önkéntes különleges kutató-mentő egységek alkotnak) szervezetei tevékenységükből adódóan elsősorban csak önmentesítésre készülnek, a megfelelő eszközök minimum mintarendszerként már rendelkezésre állnak. A polgári védelmi szakterületen megfontolandó és érdemes lenne egy napjaink kihívásainak megfelelő követelmény- és eszközrendszer kidolgozása.

\section{RENDŐRSÉG}

A Készenléti Rendőrség, a Terrorelhárítási Központ, a Köztársasági Őrezred és az Országgyűlési Őrség fő feladata a védett (VIP) személyek mentesítése mellett, itt is elsősorban az önmentesítés, ehhez a Katasztrófavédelemnél vagy a honvédségnél megjelent személyi mentesítő rendszerek alkalmasak. Új elemként jelenik meg a Készenléti Rendőrségnél az EU-forrásból beszerzésre kerülő CBRN-E mentesítő jármű, amely nagyon gyorsan bevethető, korszerü megoldás lehet a VIP-személyek kimenekítéséhez is.

\section{IPAR, MEZŐGADASÁG}

A veszélyes anyagokkal foglalkozó üzemeknél ma is üzemeltetői kötelezettség a súlyos balesetek elleni védekezéshez szükséges képesség fenntartása [1]. Ezek a képességek az üzem területén állnak rendelkezésre, de nem átcsoportosíthatók, hiszen azért vannak ott készletezve, mert az adott mentesítést igénylő esemény bármikor bekövetkezhet. Mezőgazdasági területeken elsősorban fertőtlenítési feladat adódhat, és bár ez a képesség csak tágabb értelmezésben kapcsolódik a mentesítéshez, azonban a megfelelően kiválasztott eszközök egy nagyobb katasztrófahelyzet esetén egyes részfeladatokra alkalmazhatóak/átcsoportosíthatóak lehetnének (elsősorban területmentesítési, épületfertőtlenítési, belső tér mentesítési feladatok esetén).

\section{EGÉSZSÉGÜGY}

(FERTŐTLENITÉS - MENTESÍTÉS KÉRDÉSKÖR)

Az egészségügy területén nemcsak a vírusok és baktériumok által okozott fertőzéseknél lehet szükség a fertőtlenítésre. A fertőtlenítéssel kapcsolatos kérdéseket természetesen magas szinten kezelik. Ugyanakkor az ABV-szenynyeződés nemcsak azon személyek számára jelent veszélyt, akik a hatása alá kerülnek, hanem azok számára is, akik érintkezésbe kerülhetnek velük, illetve akiknek a feladatuk végrehajtása során érintkezésbe szükséges kerülniük velük. Tanulságos példa a tokiói metrón történt eset, ahol szarin nevű idegmérget alkalmazott egy szekta. „... a szenynyezett ruházat további mérgezéseket okozott a beteggel érintkezők körében. A szarin képes párologni és levegőn keresztül terjedni, ezért a támadásnak másod-, harmad- és negyedfokú fertözöttjei is voltak. ... Körülbelül 110 orvos foglalkozott a betegekkel, akik a mérgezést követően taxival vagy gyalog érkeztek a kórházakba. A mentésben résztvevő
1364 fő szakszemélyzet tagjai közül 135-öt ugyancsak kórházba kellett szállítani. A fertőtlenítés feltételeivel nem rendelkező kórházak azt eredményezték, hogy az áldozatok száma jelentősen megnövekedett és még olyanok is áldozatul estek, akik viszonylag enyhe mérgezést szenvedtek" [2].

Az Országos Mentőszolgálat szakdolgozói elsődleges beavatkozóként érkeznek a helyszínre, s a napi munkájuk során előfordulhat, hogy ABV-szennyezett környezetből evakuált (vagy ott lévő) személy(eke)t kell egy kijelölt kórházba eljuttatniuk, miközben részére (részükre) mindazon ellátási műveleteket biztosítaniuk kell, amiket normál körülmények között is. Nagyon fontos a megfelelő felkészítés, hiszen az ABV-szennyeződés nem mindig azonosítható egyértelműen.

Ha az ABV-szennyezés elég nagy valószínűséggel megállapítható vagy feltételezhető, akkor is előfordulhat, hogy szükséges a sérült személyek ellátásának mielőbbi megkezdése. Amennyiben a beavatkozás már azok szennyezett állapotában is elengedhetetlen, akkor a beavatkozó személyzet számára a múvelet teljes ideje alatt gondoskodni kell a megfelelő személyi védelemről és biztonságról. Emiatt megfontolandó, hogy a mentőjárművek állománya számára összeállított egyéni mentesítő csomagot néhány speciális kiegészítő eszközzel rendszeresítsék.

Ha a sérült állapota halaszthatatlan beavatkozást, illetve a lehető leghamarabb egészségügyi ellátó intézménybe való szállítást igényel, s akinél így a helyszínen való mentesítés annak időigényéből következően - megengedhetetlen kockázatot idézhetne elő, a szállítást megfelelő izolációs eszköz (pl. $B-$ vagy $A B V-h o r d a ́ g y^{31}$ ) segítségével lehet végrehajtani. A sérült személy behelyezése során, a hordágyzsák külső felületére is kerülhet szennyeződés, ezért azt - a cippzár viszszazárását követően - mentesíteni kell. A speciális hordágy mentesítését követően a szennyezett sérült szállíthatóvá válik „tiszta” környezetben, átadható az ABV-szennyezett sérültek fogadására felkészült egészségügyi intézmény részére.

A megérkezéskor előzetesen szükséges a sérült szenynyezettségének megállapítása, és ha szennyezett, akkor a mentesítésre is szükség van. A kórházak, mobil egészségügyi ellátóhelyek számára érdemes elvégezni az ABVszennnyezett, egyéni vagy tömeges mentesítési igényt okozó események kezeléséhez szükséges eljárásrendek és központi készletek aktualizálását. Megoldást jelenthet a Katasztrófavédelem vagy a Magyar Honvédség azonosítással és sebesült mentesítő képességekkel rendelkező egységeivel kötött együttműködési megállapodás.

Ha a sérültnél a helyszínen történő ellátás is elegendő, számára a szennyezettség jelenti a fő kockázatot. A szenynyeződött személyeket minél előbb mentesíteni kell, ezt a feladatot azonban nem feltétlenül a mentőszemélyzeteknek kell megoldania, hanem számolni lehet a társszervek kapacitásaival. A mentesítő és izolációs eszközök kezelése és helyszínre jutattása akár a polgári védelem feladata is lehet.

\section{ÚJ LehETősÉGEK A ZRíNYI 2026 PRoGram TÜKRÉBEN (2020-)}

A vegyivédelmi szakma „nagy öregjeinek” egyik ismert szólása így hangzott: „Amikor a pénznek szűkében vagy, akkor fejlessz, tesztelj és próbálj, hogy ha újra több pénzed lesz, akkorra egyértelmüen tisztázódjon, hogy mi lesz a megfelelő eszköz és anyag az ellátáshoz".

Abban a szerencsés helyzetben vagyunk, hogy a fejlesztések többsége megtörtént, a mintarendszereket kialakították és kipróbálták. A szakmai tesztek alapján - a források rendelkezésre állása esetén - a mennyiségi beszerzések elindíthatóak. A Zrínyi 2026 Honvédelmi és Haderő- 


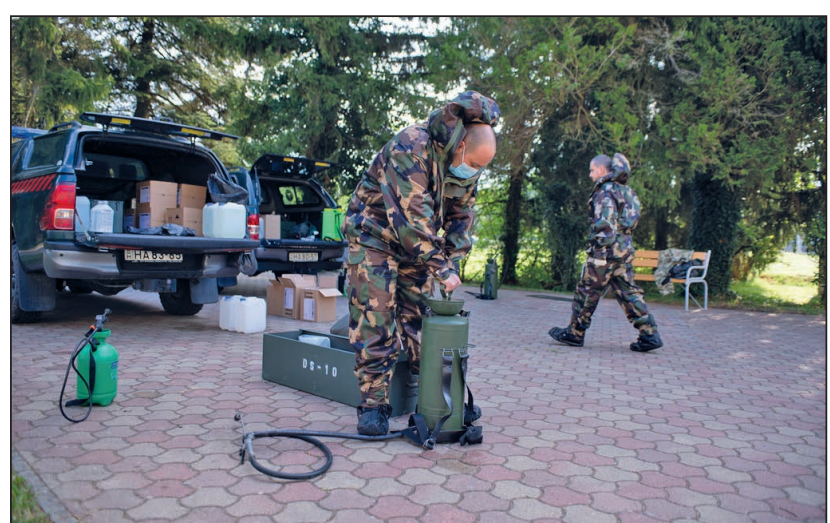

27. ábra. COVID-fertőtlenítés DS-10 készlet használatával

fejlesztési Program kiemelten kezeli a hazai védelmi ipart, és a mentesítő rendszerek többségükben ma is hazai gyártású rendszerek.

A kalcium-hipoklorit (azaz a klórmész) „ellehetetlenülése” óta nincs hazai ABV-mentesítő anyag. Ugyanakkor az elmúlt évtized tapasztalatai alapján kiderült az is, hogy a mentesítő berendezések fejlesztésekor jó iránynak bizonyult, hogy a szakma hazai megoldásokban gondolkodott. Saját megoldások biztosították a lehetőséget, és amikor egy beszállító részeleme kiesett, nem kellett kompromiszszumokat kötni. Ha a jogok és a technológia hazai kézben van, akkor szükség esetén bármely elem könnyen cserélhető, akár különleges jogrend esetén is.

A hazai termékek és a hazai referenciák megmutatták a nemzetközi együttműködésekben rejlő lehetőségeket is. A mentesítő rendszereknél kialakult értékesítési technika jó példa lehet más magyar védelmi ipari termék számára is.

A COVID-19 járvány ismét rávilágított arra, hogy a rögzített hadiipari kapacitások (RHK) és az állami céltartalékok (AC készlet) rendszerére szükség van.

\section{KöVETKEZTETÉSEK}

A mentesítő rendszerek fejlesztése Magyarország NATOcsatlakozását követően az egyik olyan jó példa, amit követni lehet egyes új védelmi ipari beszerzések során. A kezdetben kényszerű nemzetközi együttműködésektől, rövid idő alatt el lehetett jutni a közös fejlesztésekig, gyártásig és a külföldi értékesítésekig. A Zrínyi 2026 Honvédelmi és Haderőfejlesztési Programban és az Irinyi-tervben is nevesített cél a hazai védelmi ipar fejlesztése. A program lehetőséget biztosíthat arra, hogy ezen a szakterületen is jelentős előrelépés történhessen. A Magyar Honvédség vegyivédelmi mérőeszközökkel történő ellátása egyike azon részterületeknek, ahol a felmerülő igények többségét szinte minden alkalommal sikerült hazai fejlesztéssel és gyártással megvalósítani. A mentesítő rendszerek területén ₹ิ ennek a lehetősége az elmúlt évtizedben ismét megnyílt.

A mentesítés feladata napjainkban is aktuális. Az elmúlt évek bebizonyították, hogy ezekre az eszközökre bármikor szükség lehet (vörösiszap, COVID-19). A mentesítés területén érdekelt szereplők (honvédség, katasztrófavédelem, környezetvédelem, egészségügy) beavatkozói ma már (egymást kölcsönösen kiegészítve) szerepet vállalnak mindenfajta ABV-vonatkozású katasztrófa felszámolásában [3]. Az új képességek kialakítása során így eldöntendő az is, hogy mely szervezet legyen, amely az adott területért felel, vagy az alkalmazásra kerülő berendezést működteti. (MH, BM OKF, Rendőrség, TEK, ÁNTSZ, OMSz).
Ma már minta rendszerként, valamelyik alkalmazónál, a legtöbb feladatra megtalálható a megoldás (személy-, sebesült-, technika-, terület,- érzékenyeszköz-mentesítés). A fegyveres testületek és hivatásos katasztrófavédelmi szervezetek által alkalmazásba vett berendezések korszerủek, egymással kompatibilisek. A szervezeteknél elsősorban mennyiségi bővítésekre lenne szükség, az eszközök az anyagi fedezet rendelkezésre állása esetén - hazai forrásokból is beszerezhetők.

(A szerző köszönetet mond Svendor György nyá. okl. mk. ezredes úrnak, a GAMMA Zrt. Tábori Támogató Rendszerek Divíziója vezetőjének a cikk megírásához nyújtott segítségért.)

\section{FoRRÁsOK}

[1] Kátai-Urbán Lajos, Vass Gyula, Kézikönyv a veszélyes üzemek biztonságszervezésével kapcsolatos alapfeladatok teljesitéséhez. Budapest: Nemzeti Közszolgálati Egyetem, 2014.

[2] Tamási Béla, Földi László, „A tokiói metróban végrehajtott szarin támadás katasztrófavédelmi aspektusai" Hadmérnök 6. évf, 3. szám (2011. szeptember): 73. o.;

[3] Solymosi József, Halász László, Benesóczki Imre, Svendor György, Nagy Károly, „Tennivalók az ABV védelem NATO követelményeket is kielégítő színvonalának elérése érdekében" Tanulmány, Készült a Védelmi Információs Központ Kiemelkedően Közhasznú Alapítvány megbízásából. Budapest: 2001;

\section{JeGYZETEK}

24 Csak szállítja a KMB és az SZMK készletteljességébe tartozó összetevőket.

25 A vontató jármủ rakfelületére építve (a kiegészítő felszerelés / ZMB-KF/ részeként).

26 Egyetlen sátrat vetkőző/mentesítő/öltöző terekre felosztva.

27 2010. október 4-én átszakadt a MAL Magyar Alumínium Termelő és Kereskedelmi Zrt. tulajdonában lévő Ajkai Timföldgyár Kolontár és Ajka között létesített vörösiszap-tárolójának gátja.

28 A SARS-CoV-2 vírus által a COVID-19 (koronavírus) elnevezésű betegséget okozó világiárvány.

29 Közszolgáltatást végző szervnek minősül - függetlenül attól, hogy milyen szervezeti formában müködik - az állami vagy önkormányzati feladatot ellátó, illetve e feladat ellátásában közreműködő szerv, a közüzemi szolgáltató, az egyetemes szolgáltató, az állami vagy európai uniós támogatás nyújtásában vagy közvetítésében közreműködő szervezet, a jogszabályban közszolgáltatásként megjelölt tevékenységet végző szervezet, valamint a jogszabályban előírt, kötelezően igénybeveendő szolgáltatást nyújtó szervezet.

30 Bár a mentesítés szó szerepel a megnevezésében, s ilyen célt is szolgál, ugyanakkor ezeket az egyéni ABV-védőfelszerelések körébe soroljuk. Ezekkel a csomagokkal csak megelőző jellegü önmentesítési részműveletek hajthatók végre (a szennyeződés észlelésekor azonnal).

31 Mind a B-hordágy, mind az ABV-hordágy alkalmas a beteg monitorozására, a hordágy készletébe tartozó kesztyük hozzáférést biztosítanak a beteghez, amennyiben beavatkozás szükséges. A sérült szállítását követően a mentőjármủ ismét alkalmas feladatellátásra, csak a hordágy belső felületének fertőtlenítése/ mentesítése szükséges.

B-hordágy: biológiailag fertőzött sérült szállitása esetén a mentőhordágyhoz adaptálható biológiai védőkeret, amely lehetővé teszi a sérült szeparált monitorozását is.

ABV-hordágy: Biológiailag fertőzött sérültön túl akár sugár- vagy vegyi anyaggal szennyezett sérült szállítását is lehetővé teszi a mentőhordágyhoz adaptálható ABV-védőkeret. 